\title{
Citizens in the Making: The Inclusion of Racialized Subjects in Labour Market Projects in Sweden
}

Viktor Vesterberg and Magnus Dahlstedt

Journal Article

Tweet

N.B.: When citing this work, cite the original article.

Original Publication:

Viktor Vesterberg and Magnus Dahlstedt, Citizens in the Making: The Inclusion of Racialized Subjects in Labour Market Projects in Sweden, Scandinavian Political Studies, 2016 http://dx.doi.org/10.1111/1467-9477.12084

Copyright: Wiley: 24 months

http://eu.wiley.com/WileyCDA/

Postprint available at: Linköping University Electronic Press

http://urn.kb.se/resolve?urn=urn:nbn:se:liu:diva-132401

1.UU UNNENRESSIIET 


\title{
Citizens in the making - the inclusion of racialized subjects in labour market projects in Sweden
}

\author{
Magnus Dahlstedt \& Viktor Vesterberg
}

\section{Abstract}

This article analyzes the formation of citizenship in today's multi-ethnic Sweden in the light of the inclusion of 'people with foreign background'. Particular focus is put on how ethnicity and migration renders visible existing citizenship ideals, defined in terms of similarity and difference on the basis of ethno-cultural background. The formation of citizenship is analysed in the case of labour-market projects targeting racialized migrants. The point of departure is an understanding of citizenship as an on-going process of citizen formation, highlighting the formation of citizens as rights-bearing subjects, belonging to the societal community - in contrast to those not bearing these rights and not belonging to the societal community. The analysis illustrates how norms of Swedish-ness condition the membership in the Swedish societal community, forming a particular kind of racialized citizenship, including certain subjects, under certain conditions, while excluding others. One conclusion is that in addition to the formal dimensions of citizenship, the ability and willingness to adapt to norms of Swedish-ness is essential for accessing and using social rights i.e. for becoming employable and included on the labour market. In the projects analysed, racialized migrants have the duty of becoming employable by embracing certain values - the good, working citizen, the free, independent individual, able to make choices - all constituted as being part of the ideal Swedish citizenship.

\section{Introduction}

Sweden has for quite a long time had an international reputation of having developed a welfare regime based on the principles of social equality, solidarity and democracy. Sweden has also an international reputation for its generous immigration policies as well as for its inclusion of migrants. However, as indicated by recent developments in the 'refugee crisis' in Europe, this conceptualization of an equal and inclusive Swedish citizenship is being substantially challenged. 
Since 2015, more than a million people have been seeking refuge in Europe. Most of them have come from the war-torn Syria (International Organisation for Migration 2015). Throughout the member states of the European Union, among these also Sweden, exceptional policy measures are being taken in order to handle the so-called 'refugee crisis' - intensified border control, the introduction of identity checks at specific checkpoints as well as within the borders of a country, and restrictive rules for the reception of asylum seekers.

This precarious situation addresses a number of crucial questions about the state of citizenship and belonging in an age of large-scale international migration in which established conceptions of citizenship, of who the citizen is or should be, are challenged. The current situation clearly illustrates the following rationality of citizenship: inclusion into the community of citizens, with the same rights and obligation, in some way or another presupposes the existence of non-citizens, i.e. exclusion of some subjects. As will be shown in this article, this is also - and has been - the case in the inclusive welfare and integration regime in Sweden.

International migration highlights some of the fundamental issues of citizenship: which characteristics, abilities or values should the citizen have and how are the relationship between citizen and society arranged? In the context of international migration certain individuals are seen as naturally belonging to the national community they inhabit, guaranteeing a set of rights, while others are seen as not belonging. The question, however, is: Who are actually included in the societal community, on what conditions, who are excluded, and on what conditions?

This article analyzes the formation of citizenship in multi-ethnic Sweden with a particular focus on how ethnicity and migration renders visible existing citizenship ideals, defined in terms of similarity and difference on the basis of ethno-cultural background. The formation of citizenship is analysed in the implementation of labour-market measures targeting unemployed 'people with foreign background" in Sweden. The over-arching question of this article concerns how unemployed 'people with foreign background' are included in the community of citizens by measures of increased employability and on what conditions. The theoretical point of departure is a Foucauldian understanding of citizenship as an on-going process of citizen formation. In line

\footnotetext{
1 The term people with foreign background is frequently used in Swedish labour market policy as well as more broadly. Statistics Sweden's definition of a person with a foreign background is someone born abroad or born in Sweden with two parents born abroad (Statistics Sweden 2016b). When this term is used in the article, it refers to how it is used in the empirical material. For analytical purposes, we use the concepts of racialization and racialized migrants referring to those migrants constructed different on the basis of racial, ethno-cultural and/or religious categorisations (these concepts are elaborated in more detail below).
} 
with such an understanding, the analysis highlights the formation of citizens as rights-bearing subjects, belonging to the societal community - in contrast to other subjects, not necessarily bearing the same rights, having equal opportunities, i.e. not seen as 'naturally' belonging to the societal community as equal citizens. In this on-going formation of citizens there is a constant tension between inclusion and exclusion, normality and deviance, those belonging and those not belonging to the societal community. It is the boundaries drawn between Us and Them and the asymmetrical relationships created through these boundaries that are the focus of our analysis.

The outline of the article is the following: Firstly, the analytical framework of the article is presented. Secondly, the topic of the article is set in the context of Swedish welfare and integration policy. Thirdly, the analysis of the empirical case is carried out. In the final section, the main conclusions are summarized and discussed in relation to some of the challenges of contemporary multi-ethnic citizenship in Sweden.

\section{The making of citizens}

The contemporary discussion on citizenship in social sciences has its starting point in T.H. Marshall's (1950) conception of citizenship as a membership of the societal community. According to this conception, citizenship is based on a contract between the individual and the state, guaranteeing the individual a set of rights, ranging from civil to political and social rights.

This contract is constantly rewritten and challenged, not least in relation to issues of international migration and ethnic relations (Sassen 2006). The question of inclusion into the societal community has several dimensions. For instance, as it has been emphasized, it is important to recognize the distinction between citizenship in formal and substantive terms (Marshall \& Bottomore 1992). Citizenship in a formal sense, highlight the rights as well as obligations of the citizen, guaranteed by the legal state of being a citizen. This formal dimension of citizenship is important in order to analyze the formation of citizenship, but it is equally important to highlight the broader processes of inclusion and exclusion where the substantial conditions for equal citizenship are played out - and negotiated. The question, then, is how is inclusion into the societal community made possible and on what conditions are different subjects made into included citizens?

Such processes of inclusion and exclusion raise issues about who the citizen is and what the citizen should be like as well as societal conditions for becoming a citizen (see e.g. Isin \& Wood 1999). One particular theoretical perspective highlighting such dimensions of citizenship is influenced by Michel Foucault and his ideas about power and governing (White \& Hunt 2000; 
Procacci 2004; Ong 2006; Dahlstedt 2009). On the basis of this understanding of citizenship, Barbara Cruikshank (1999: 3) has stated that: 'Citizens are not born, they are made.' In this light, citizenship can be seen as having no pre-given meaning or essence. Thus, citizenship could be analysed as an on-going formation of citizens as subjects, i.e. citizens are constantly in the making. These processes of citizen formation are not one-directional, directed from the top down, where citizens, the 'objects' of governing, are 'passive' (Foucault 1991). Rather these processes could be understood as complex power relations wherein citizens are shaped into citizen-subjects.

In line with this perspective, it is crucial to further analyse the regimes of truth (Foucault 1980), defining how citizens should appear, behave, and think as 'good citizens.' In the on-going formation of citizens as particular kinds of subjects, citizen-subjects are formed in a continuum between the normal (i.e. the ideal citizen) and the deviant others (i.e. those lacking the virtues and competences of the ideal citizen). Inclusion and exclusion is here not a matter of either or, either included or excluded - rather, they presuppose one another. Citizens may be formally included into the societal community in the sense of being granted the formal rights of the citizens, but at the same time they may be in the position of not really being able to access or substantially exercise these rights. Thus, when analysing the formation of citizenship, it is crucial to further analyse the intimate relations between inclusion and exclusion, constructions of the norm as well as the deviant. This point has also been emphasized by Engin Isin (2002: 3f), approaching 'otherness as a condition for citizenship', arguing that 'citizenship and its alterity always emerged simultaneously in a dialogical manner and constituted each other'.

In today's 'advanced liberal society', the ideal citizen is characterized as the free and responsible individual (Rose 1999). Governing here is about the constant creation of 'responsible citizens' who take charge of the entire course of their own lives on the basis of their own ideals, circumstances, and ambitions. The rationale behind these interventions is implanting in citizens the aspiration to pursue their own civility, wellbeing and advancement' (Rose 1996: 40)—in other words, the aim is creating individuals who are, by their own efforts, motivated, willing, and able to take the initiative of shaping their own futures. The formation of such citizens involves a range of technologies, systems of knowledge and expertise, operating throughout society (Dean 1999).

On the basis of this perspective, researchers have related citizenship to issues of migration, ethnicity, nationhood and the inclusion/exclusion of migrants (cf. Dillon 1995; Stoler 1995; Lui 2004; Werry 2008). These researchers have shown how categories such as ethnicity, nation, and race have played a crucial role in the formation of citizenship and the governing of citizens. Such 
categorisations have been important in the formation of 'good citizens,' differentiating Us from Them, similarity from difference, normality from abnormality (Dean 1999). From this theoretical point of departure, we deploy the concepts of racialization and racialized subjects when further analysing processes of citizen formation. Here, racialization is understood as processes constructing differences on the basis of racial, ethno-cultural and/or religious categorisations, in relation to what is understood as normal (cf. Hall 1996; Miles \& Brown 2003; Goldberg 2009). In these processes of constructing differences (Hall 2000), certain subjects are positioned as deviant in relation to a normalized 'national belonging' - in the particular case analysed in this article Swedish-ness. The subjects constructed through these processes we refer to as racialized subjects.

Contemporary discourses on citizenship were historically developed within the frame of the nation-state and nationalism as political doctrine, in the second half of the 19th century. Here membership for the individual in the societal community was strongly tied to the nation, where the ideal was one people, one territory, one culture, one religion and one language (Eriksen 2002). The contract defining the content and scope of citizenship has been formulated within the framework of the national community and its principles of inclusion and exclusion.

Some parts of the population have been regarded as 'naturally' belonging to this community while others have been defined as 'strangers', especially racialized migrants, who have appeared almost as a kind of anomaly in the national order of things (Malkki 1997). In an age of globalization and international migration, citizenship is increasingly blurred as these migrants are challenging the very existence of national citizenship by crossing the seemingly natural boundaries of the nation-state (Tesfahuney \& Dahlstedt 2008).

Citizenship may be organized differently in different countries, on the one hand related to how the welfare model is built and on the other hand on how the national community is formed. A range of scholars have shown how citizenship is organized in various ways in different countries, related to the specific historical development of each country (cf. Koopmans \& Stratham 2000; Borevi 2010). When it comes to the question of how the national community is defined, we can schematically discern two forms of ideal types of national identity, which can take somewhat different shapes in different countries.

One form of national identity is built on the conception of the citizen as necessarily born in a country, in order to be included in the national community, enjoying the rights of citizenship. Citizenship is accordingly derived from the principles of kinship, descent or blood (jus sanguinis). The other form of national identity is built on the conception of the citizen as residing in a 
certain country, sharing common values of this community (jus solis). Citizenship is here defined in relation to the territory of the state, independently of ethno-cultural divisions. All people permanently residing in a particular territory, subjecting themselves to the core values of the community, are in principle included as equals (Brubaker 1992, 1996).

With the analytical framework guiding the analysis in this article, the focus is put on the ways in which norms of citizenship ideals are constructed, in relationships between inclusion and exclusion. These norms are constructed by similarity and difference, on the basis of ethnocultural roots and descent (jus sanguinis) as well as 'inclusive' values (jus solis). How categories such as ethnicity, culture and values are actually played in the formation of citizenship and the governing of citizens is an issue that needs to be further analysed in particular empirical settings.

\section{Welfare and multiculturalism - the Swedish way}

The Swedish welfare model, developed in the post-war period, has had a quite astonishing international reputation as being a successful 'middle course' between capitalism and socialism. This particular welfare model was based on the pillars of centralism and universalism, social intervention, and consensus (Rothstein 1998). As Esping-Andersen summarised in his important contribution on welfare regimes, the social democratic version entailed

... a mix of highly de-commodifying and universalistic programs that, nonetheless, are tailored to differentiated expectations. Thus, manual workers come to enjoy rights identical to those of salaried white-collared employees or civil servants; all strata are incorporated under one universal insurance system, yet benefits are graduated according to accustomed earnings. This model crowds out the market, and consequently constructs an essential universal solidarity in favour of the welfare state. All benefit; all are dependent; and all will presumably feel obliged to pay (EspingAndersen 1990: 28).

The Swedish welfare model was based on the so-called work line doctrine, with the goal of full employment, i.e. that everyone who was able to should as far as possible be in work (EspingAndersen 1990; Junestav 2007). The model was also characterized by 'a readiness to give democracy considerable scope in substantive terms, [as] democratic organizing was regarded as natural and desirable in virtually every facet of society, [with] an emphasis on lively democratic participation... especially in popular movements and political parties' (Premfors 2000: 163). 
However, starting in the late 1980s, several of the cardinal principles underpinning the Swedish model was challenged and criticised for its alleged inefficiency and highly centralised micromanagement, which was said to stand in the way of individual initiative, hampering people's will to participate and have their say (Boréus 1994; Hugemark 1992). The economic crisis in the early 1990s was 'the final blow to Swedish welfare policies as we once knew them' (Larsson et al 2012: 3). The categorization of the Swedish model as the epitome of a classical social democratic welfare regime has thus been challenged, due to the global policy trends of individualization, marketization, decentralization and privatization. What gradually emerged, according to Premfors (2000: 175), were the contours of 'a new Swedish model', with a growing emphasis on power and participation 'from below', 'a model that combines continued and further elaborated welfare policies with a highly noticeable decentralization of politics and administration'.

The Swedish welfare model has often been described as a pioneer in terms of inclusion of migrants. Sweden has hereby appeared as a symbol of the citizenship model described by Stephen Castles (1995) as multicultural, a model based on the principles of inclusion (making it relatively easy to obtain citizenship) and recognition (guaranteeing minorities certain group rights). Regarding the formal civil, political, and social rights described by Marshall, in Sweden there have traditionally been no major differences between those born in Sweden of native Swedish parents and those born abroad or in Sweden to parents who are foreign born. All those granted Swedish citizenship have the same formal rights, regardless of ethno-cultural background.

However, in the early 1990s, Aleksandra Ålund and Carl-Ulrik Schierup (1991) described Swedish multiculturalism and the inclusion of migrants in Sweden as quite paradoxical. They highlighted tensions between citizenship in the formal and the substantive sense. In spite of the ambitions of including migrants and making them full members of the Swedish societal community, bearing the same formal rights as native Swedish citizens, the substantive societal living conditions of the included migrants do not match these ambitions. In line with this argument, a number of studies have more recently indicated similar tensions between ambitions and conditions in all three dimensions of citizenship rights-from the justice system (civil rights) (Diesen, 2005, 2006) to politics (political rights) (Bäck \& Soininen 1996; Rodrigo Blomqvist 2005; Dahlstedt \& Hertzberg 2007) and to the educational system, the labour market, and housing (social rights) (Schierup, Hansen \& Castles 2006; Gruber 2007; Boréus \& Mörkenstam 2010; Ngeh 2011).

In order to further understand the emergence of such tensions, it is crucial to conceptualise the citizen as something in the constant making. In this regard, the analytical perspective elaborated above may be useful as it highlights the formation of citizens as rights-bearing subjects, belonging 
to a particular societal community - in contrast to those subjects not bearing these rights and not belonging to the societal community. From this perspective, then, we will in the following analyse the formation of citizenship in one specific empirical setting; the implementation of labourmarket policies targeting 'people with foreign background' in Sweden. In our analysis of such policies, we focus on practices of citizen formation where an employable citizen is constructed as the norm, characterised by certain values, characteristics, and abilities, in relation to those constructed as problematic and un-employable others. Particular emphasis is here placed on the formation of normal employable citizens in relation to racialized migrants, appearing as atypical and problematic.

\section{Methods and empirical material}

In Sweden as well as in many other countries in Europe and elsewhere, employment has become increasingly intertwined with social inclusion and citizenship. Accordingly, both unemployment and social exclusion is seen as among the most urgent challenges for the contemporary welfare state (Larsson 2015). Due to these developments, the empirical focus of this article is projects of labour market inclusion arranged in the context of the European Social Fund, ESF. ESF is one of the most influential means of combatting social exclusion among 'people with foreign background' and other 'vulnerable groups' - to use the regular ESF terminology - in Europe, not least when it comes to promoting inclusion on the labour market (Vesterberg 2016). The empirical scope of the article is labour market projects targeting unemployed 'people with foreign background', co-financed by the ESF. In the practices of inclusion initiated in these projects, the enhancing of 'employability' is one of the main priorities. In the analysed projects 'people with foreign background' is constructed as a particular target group, in need of certain measures. These measures may apply to different categories of unemployed. However, in this article the focus is on projects particularly targeting 'people with foreign background' and the ways in which this group is constructed as not (yet) employable and thus responsible citizens.

Among the most frequent approaches for enhancing the employability of the unemployed in the ESF projects are education, work placement, and job coaching, usually in combination (Engstrand, et al. 2010). In Sweden, the ESF has hitherto co-financed over 90000 projects, involving more than one million participants. Projects co-funded by the ESF are particularly important to examine regarding how the target groups are constructed as employable citizens as the ESF is today a major channel for disseminating and implementing EU policies to its member states and for attempting to influence how social and labour market policies are formulated and implemented (Jacobsson 2004). 
The analysis is based on ethnographic fieldwork carried out between 2009 and 2010, including interviews with unemployed people participating in ESF projects and staff working in these projects, as well as participant observations in several projects (cf. Engstrand, et al. 2010; Vesterberg 2016). In total, the ethnographic material consists of 15 days of participant observation and 12 qualitative interviews spanning from one to two hours each. As part of the ethnographic fieldwork, information material and project plans describing the aims and means of the projects were also collected. The interviews were recorded and transcribed in their entirety. This material has been analysed with the theoretical framework presented as point of departure. In this analysis, we have chosen a number of empirical examples illustrating the main argument in the article - i.e. that practices of citizen formation operate in a nexus of inclusion and exclusion, constructing the norm and the deviant.

\section{Analysing the making of employable citizens}

During the economic crisis in the 1990s unemployment increased dramatically in Sweden, particularly affecting racialized migrants (Schierup \& Paulson 1994). In 2016, unemployment among foreign-born was 16.6 per cent, compared to 5.4 per cent among Swedish born (Statistics Sweden 2016a). People with foreign background are over-represented not only among the unemployed, but also in jobs with lower wages, poorer working environments (Hjerm 2002), and poorer employment conditions (Jonsson \& Wallette 2001).

In line with the changing welfare politics of the 1990s, there was a quite dramatic shift in labour market policy. Work was increasingly conceptualized as an individual duty rather than a social right (Junestav 2007; Hörnqvist 2010). As the political focus in the 1990s shifted from the lack of jobs to the lack of employability, both success and failure in working life was attributed to the qualities, dedication, and ability of the individual to make herself employable (Garsten \& Jacobsson 2004; Chertkovskaya, Watt, Tramer, Spoelstra, 2013).

The conception of work as an individual duty is not least targeting racialized migrants, as they are overrepresented among the unemployed (Behtoui 2006). There is a concern that after long-term unemployment, they can get stuck in a kind of 'social exclusion' - a paralyzing existence outside the majority society. Emphasizing work as an individual duty seeks to prevent social isolation and passivity and to evoke activation and a sense of responsibility among the population. Thus, it is crucial to further analyse activities initiated in order to make targeted subjects employable and included in working life. In the following, we focus on such activities illustrating the shaping of 
racialized migrants into employable citizens, with certain values, characteristics, qualities and abilities (see Vesterberg 2016).

Welfare benefits for the unemployed are conditioned upon the participation in job-oriented activities. If the unemployed refuse the 'offer' of a particular activity, they may be denied their welfare benefits (SFS 2007: 414). The job-oriented activities offered often include education, work training, job-coaching and career guidance - i.e. activities aiming at enhancing the employability of the targeted subjects (Vesterberg 2016). Here, increasing one's employability appears as a civic duty.

The notion of Swedish-ness is a reoccurring topic in the analysed labour market projects targeting 'people with foreign background'. The adoption of 'Swedish norms' is understood as necessary in order for them to become employable and included in the Swedish labour market (cf. Hertzberg 2003). The importance of learning 'Swedish norms' is emphasized in the following way, by the manager of one labour market project:

If you are Swedish born and unemployed, you have learned social codes through your life in Sweden. For many of these individuals [i.e. those who are not born in Sweden] it will be many new elements. [...] There are many new codes to be learned. [...] When they go to coffee break-what's the chitchat in Sweden? [...] When you come to the first coffee break-what are you supposed to talk about? What is the typical conversation in Sweden?

Here, we can see how employability is explicitly tied to the notion of Swedish-ness, i.e. employability becomes racialized. As illustrated in the quote, the unemployed who are described as 'Swedish born', are seen as - seemingly by nature - well adapted to the prevailing 'social codes' in Sweden. Even though they are unemployed, they belong to the community of Us, sharing the skills necessary for being included. By learning these codes and norms those who are not born in Sweden will become employable citizens. But we can also see how the learning of such norms presuppose another reoccurring topic in the projects, Swedish language skills. Thus, those who are not born in Sweden are constructed as problematic in two interrelated ways: they do not know what to talk about (i.e. they lack knowledge about Swedish norms), neither do they know bow to talk (i.e. they lack Swedish language skills), making it even harder for them to learn the norms deemed necessary for being included.

The importance of Swedish language skills is constantly emphasized in the labour market projects. Sometime the issue of language-barriers creates tensions in the projects, not least 
between project participants. This is shown in the following quote from a conversation during fieldwork, with two unemployed talking fluently Swedish, participating in one of the projects. One of them complains about 'a bunch of Arabs chattering', giving her a headache. She emphasizes that 'they should speak Swedish here'. The other participant also highlights the issue of language in a similar way:

Many don't even want to try to speak Swedish. They know some, but they don't want to do it. Then comes this cackle; they sit there and translate for each other, and we sit here like fools, those of us who speak Swedish.

Language skills is understood as crucial in order for the project participants to be able to learn the norms deemed necessary for inclusion in the labour market as well as in society at large. How then are these norms conceptualized? A job-coach in one labour market project, defines what the unemployed participants are to learn in terms of learning to 'make their own choices' and to 'take responsibility'. Thus, the employable citizen is understood as having the desire and ability to make choices and to take responsibility for the outcome of these. She further emphasizes 'the importance of being clear about what you are good at, to look forward [...] and to know what you want'. To become employable, the individual needs to see herself as an unfinished project, constantly shaping herself according to the needs and expectations of the employers. This means acquiring a positive attitude, emphasizing one's strengths and possibilities rather than one's shortcomings, difficulties and problems.

The lack of motivation and self-confidence are understood as pertinent problems for the unemployed racialized migrants. As one job-coach emphasizes, confidence is particularly important when it comes to presenting oneself as employable for potential employers: 'Confidence is important when we market ourselves. Who wants to buy a product that not even the seller believes in?' The self-presentation of the unemployed is here understood in terms of marketing: the employable self is a commodity for sale.

The role of the job-coach is then to make the unemployed responsible for their employability. As another job-coach describes, his role is the following:

I'm trying to put the responsibility on the individual. But it is a matter of assessing and testing how much a person can handle [...]. I'm trying to push the clients to the limit, so that they take their own responsibility. 
In this reasoning the employable Swedish citizens is conceptualized as being responsible for problems as well as possibilities in the labour market. Once more, the challenge is to get the unemployed to make the right choices and to take responsibility for them. Thus, being an employable citizen requires the willingness and ability to choose, where one is to 'optimize [one's] choices, efficiency and competitiveness in turbulent market conditions' (Ong 2006: 6). The ideal citizen emerges as an enterprising subject, seeking to promoting herself and to maximize her human capital (Rose 1998: 154).

The employable citizen is always constructed in relation to its opposite-in the interviews repeatedly in relation to the problematic unemployable other, as illustrated in a quote where one job-coach describes this typically problematic subject.

A man who has lived in Sweden for 15 years and never had a job and cannot write two sentences in reasonably good Swedish. He lacks motivation, the tools, and the means to accomplish something [...] He is not attractive for an employer.

This racialized subject emerges as someone lacking the skills, qualities and abilities making a citizen employable and thus responsible. This particular subject is constructed as deviant and in need of being transformed into normality, implicitly defined in terms of Swedish-ness (Wright Nielsen 2009; Vesterberg 2016). This 'normal' Swedish citizen appear as motivated, able and willing to learn how to become employable. In a way, being employable equals being 'Swedish'. In a similar manner, another job-coach describes the 'typical case' of the problematic unemployable ‘immigrant woman' accordingly:

It may be a 49-year old immigrant woman who has passed three years at Swedish for migrants, but cannot even speak everyday Swedish. She is illiterate and has never had a job or attended school in her home country. She often comes from the Middle East and is Arabic speaking.

In both of the quotes above, the formation of the employable citizens is racialized as well as gendered, where boundaries are drawn between the employable Swedes and the unemployable others. The 'immigrants' above - the woman as well as the man - emerges as racialized opposites to the ideal employable citizen - the free, independent individual, able to make choices. These characteristics are thus constituting the ideal Swedish citizen.

The 'immigrant woman', on the one hand, appears as a victim, as further illustrated in the following quote from one labour market project describing its participants as unemployed 
'women who, because of religious and cultural traditions can't reach a position on the labour market'. These women are, in other words, victims - of their cultures and traditions - making them unemployable. The role of the job-coach then becomes that of 'liberating' them from their cultures and traditions and making them employable and included into the gender equal Swedish societal community.

In the descriptions of the 'immigrant women', there is most often also an implicit understanding of the 'immigrant man', as illustrated in the following quote from a project employee describing the challenges in working with unemployed 'immigrant women':

Many come from cultures where women especially are not accustomed to think for themselves, for they are used to being told what to do, and then follow.

Here, the 'immigrant women' are explicitly described as problematic, being victims. In relation to these women, the 'immigrant man' is implied as being particularly problematic — as the one telling the women what to do and how to think, i.e. the offender, the traditionalist patriarch. In the quote, it is also implied that 'Swedish culture' is based on gender equality, where women are accustomed to being independent and responsible citizens. In all, the racialized migrant women are constructed as unable to visualize a realistic future for themselves as working and responsible citizens, while the racialized migrant men are implicitly constructed as the ones limiting the women's possibilities of becoming such citizens.

A similar logic appears in the written summary of the same project. In this summary, the category of 'immigrant women' is described as 'illiterate and having weak skills in Swedish', bearing 'religious and cultural traditions' hindering them from 'reaching a position in working life', and thus from becoming an equal member of the societal community. Once more, the focus is put on the women, while the men are not explicitly problematized in terms of ethno-culturally marked gender relationships. In the same project summary, these women are constructed in contrast to a range of categories of unemployed 'Swedes', characterized not in terms of religion and culture but in other ways: 'Swedish academics... who have not reached a position in working life due to their way of being', as unemployed 'on long-term sick-leave and ex-drug abusers', both 'in need of social training and regular habits in order to return to a life outside their homes'. The quote illustrates that this project are in fact targeting different groups, and not just one. However, the reasons put forth for why these different groups are unemployed and in need of particular measures enhancing their employability differ. When it comes to unemployed 'people with foreign background', the main explanatory factor put forth in is their background and belonging, 
language skills, culture and religion, while there are several explanatory factors for the categories of unemployed Swedes, ranging from sickness to drug-abuse and individualised 'ways of being'. Thus, the racialized migrants are constructed as bearers of 'their cultures', 'Swedes' as individuals.

How, then, can the unemployed racialized migrants relate to the expectations and demands targeting them in the labour market projects? One illustrative example derives from one of the projects analysed. During participant observation in the project, the following, scene is played out: One participant comes to the project on his first day. In a positive spirit, he said: 'All I want is a job!' The project employee tells him that first he needs to practise his language skills. Then he needs to go to work placement. And then he may be ready to take on a regular job. In this scene, the employee constructs the racialized subject's route to employment as a path consisting of several steps leading towards employability - and thus inclusion. However, the prescribed routes to employment - learning the Swedish language, going to work placement, and then seeking regular wage work - are contested by the same project participant. While talking about work placement, one of the prescribed routes to employment, this specific route is portrayed as an inescapable circle of unpaid work, particularly for those not categorized as 'Swedes', rather than as a straight path towards a regular employment:

Swedes do work placement once, and then they get a job. I do work placement after work placement after work placement, but I don't get a job. I don't want it to be like this anymore!

Once more, there is a distinction made between the categories of 'Swedes' and others, i.e. 'nonSwedes'. In the quote, the project participant describes a major discrepancy in the opportunities to actually get an employment after finishing the project, depending on whether you are considered a 'Swede' or not. Although this is the experience of a particular unemployed, the experience as such is not at all unique. Rather, as research has shown, racialized migrants are in a highly precarious situation in the Swedish labour market (cf. Jonsson \& Wallette 2001; Hjerm 2002; Behtoui 2006; Neergaard 2006).

Understanding these labour market projects in terms of practices of citizen formation illustrate the making of unemployed racialized migrants into employable Swedish citizens. In the projects analysed, these migrants have the duty of becoming employable, with the guidance from jobcoaches and project employees. Un-employability can be turned into employability if the unemployed racialized migrants embrace certain values, ways of thinking and being, both 
implicitly and explicitly related to norms of Swedish-ness, the desirable and the normal - the good, working citizen.

\section{Concluding reflections}

In this article we have analyzed the formation of citizenship in multi-ethnic Sweden in the case of inclusion of racialized unemployed migrants on the Swedish labour market. The over-arching question has concerned how unemployed 'people with foreign background' are included in the community of citizens by measures of increased employability and on what conditions. By analyzing labour market projects targeting 'people with foreign background', we have focused on the racialization of unemployed migrants renders visible current citizenship ideals, defined in terms of similarity and difference on the basis of ethno-cultural background, religion and language skills. The analysis illustrates the ways in which norms of Swedish-ness condition the membership in the Swedish societal community, forming a particular kind of racialized citizenship (cf. Hansen 2013), including certain subjects, under specific conditions, while excluding others. The analysis has shown how both inclusion and exclusion is made possible by distinctions made between 'Swedish' and others, non-Swedish on the labour market. One conclusion is that the racialized migrants' ability and willingness to adapt to norms of Swedishness is essential for accessing and using social rights - i.e. for becoming employable and included on the labour market. As shown in the analysis, the main responsibility for becoming included in the societal community by employment is first and foremost placed on the individual - in line with current developments in welfare policy, taking place in Sweden as well as in several other countries (cf. Schierup, et al. 2006; Larsson et al. 2012).

In formal terms, the background of the individual should have no impact on their rights and obligations as citizens - since all citizens are formally equal. However, as shown in the analysis, the ways in which the individual citizen is constructed in terms of belonging - their difference and similarity - do have an impact on the substantial opportunities of actually exercising these rights. Here, 'inclusive' values such as gender equality, responsibility, freedom of choice and equal opportunities - in one way or another - presuppose exclusion, i.e. subjects who do not live up to these values, but who are yet to become includable. This mutual relationship between inclusion and exclusion becomes apparent in today's Sweden, in an era of large-scale international migration. In Sweden, current values formally open up for all members of society, 'Swedes' and 'migrants' alike, to become equal citizens, as long as they follow the rules, norms and obligations of the community. Yet, at the same time, particularly strong demands of adapting to seemingly pre-given norms and values are put on those migrants racialized as being ethno-culturally deviant. 
Demands such as having proper language skills - knowing how to talk and what to talk about in specific situations - being motivated and having adopted core values of society may apply to different categories of unemployed. However, when such demands are targeting 'people with foreign background', these demands are marked in terms of Swedish-ness, i.e. the inclusion and exclusion on the labour market as well as in society becomes racialized.

As we have argued in the article, it is important to conceptualise the citizen as something in the constant making, i.e. as an on-going process of negotiation, concerning both the boundaries and content of citizenship. This way of conceptualising citizenship may seem paradoxical, considering the argument presented above. How could the citizen be seen as constantly changing while she at the same time is supposed to adapt to a set of seemingly pre-given norms of Swedish-ness? It is this tension in the formation of citizens and citizenship that has been the focus of this article. In the formation of citizens and citizenship there is a constant tension between change and stability, inclusion and exclusion, normality and deviance. These processes of citizen formation involve a range of subjects, not least migrants. Here, migrants are not passive targets for governing practices, but rather active participants taking part in the shaping of both themselves as citizens and the societal community. In the analysis, we have shown how such negotiations may occur in the context of labour market inclusion, for instance when work placement in one of the projects analysed was contested by one of the participants, as a fruitful route to actual employment for those unemployed who are not categorized as 'Swedes'.

As citizenship is an on-going negotiation, issues of rights and belonging are always at the core of political debate - not least in the context of contemporary international migration and the socalled 'refugee crisis' in Europe post-2015, challenging the understandings of who belongs to the societal community and who should have access to the rights of citizenship. With this 'crisis', further political focus has been put on the crucial political question addressed in the beginning of this article: Who should be included in the societal community, and on what conditions, and who should be left out? This particular question is at the very centre of the political debate in Europe of today. On the one hand, there are strong arguments about the 'death of multiculturalism', and the demands, also in Sweden, for new forms of ethno-culturally graduated citizenship (Dahlstedt \& Neergaard 2015). Policy developments and political discourse in Sweden since 2015 have quite dramatically intensified the racialization of inclusion and exclusion highlighted in this article. In tandem with the current 'refugee crisis', there has been an increasing focus on the 'problems' of migration and integration where policies have been adopted in order to 'secure' the national borders and decreasing migration (Prop. 2015/16:174). At the same time, there has been a strong 
emphasis on 'Swedish values' in political discourse, where a range of values are marked as specifically 'Swedish’ (cf. Kinberg Batra \& Norlén 2016; Löfvén 2016). With these developments, migrants are increasingly problematized as ethno-culturally deviant, further racializing the politics of inclusion and exclusion into the Swedish societal community.

On the other hand, in Sweden as well as in other European countries, claims have been made for the development of a new and more inclusive societal community which expands the rights of citizens by accommodating those who have previously been excluded. These demands have been made collectively as well as individually, publically as well as more privately, loudly as well as more quietly. For instance, in suburban areas throughout Sweden, there has been a rise of social movements where youth, both born in Sweden and abroad, have been actively involved in claiming their right to belong, struggling for equal social rights and challenging current notions of citizenship in contemporary multi-ethnic Sweden (de los Reyes et al. 2014; Schierup et al. 2014).

The outcome of these tensions and negotiations is not settled, but will be the result of contestation and political struggle, in need of further analysis.

\section{References}

Behtoui, A. 2006. Unequal Opportunities. Department of Social and Welfare Studies, Linköping University.

Boréus, K. \& Mörkenstam, U. 2010. Spjälorna i buren, Lund: Studentlitteratur.

Borevi, K. 2010. 'Dimensions of Citizenship', in: Bengtsson, B. et al. Eds. Diversity, Inclusion and Citizenship in Scandinavia, Newcastle: Cambridge Scholars.

Bottomore, T. 1992. 'Citizenship and Social Class, Forty Years On', in: Marshall, T. H. \& Bottomore, T., Citizenship and Social Class, London: Pluto Press.

Brubaker, R. 1992. Citizenship and Nationhood in France and Germany, Cambridge: Harvard University Press.

Brubaker, R. 1996. Nationalism Reframed, Cambridge: Cambridge University Press.

Bäck, H. \& Soininen, M. 1996. 'Invandrarna, demokratin och samhället', in: SOU 1996: 162, På medborgarnas villkor, Demokratiutvecklingskommittén.

Castles, S. 1995. 'How Nation-States Respond to Immigration and Ethnic Diversity', New Community, 21: 293-308.

Chertkovskaya, E., Watt, P., Tramer, S. \& Spoelstra, S. 2013. 'Giving Notice to Employability', Ephemera, 13 (4): 701-716.

Cruikshank, B. 1999. The Will to Empower, Ithaca: Cornell University Press.

Dahlstedt, M. \& Hertzberg, F. 2007. 'Democracy the Swedish Way?', Scandinavian Political Studies, 30 (2): 175-203.

Dahlstedt, M. 2009. Aktiveringens politik. Malmö: Liber.

Dahlstedt, M. \& Neergaard, A. 2015. International Migration and Ethnic Relations. London: Routledge. 
Dean, M. 1999. Governmentality, London: Sage.

de los Reyes, P. et al. 2014. Bilen brinner, men problemen finns kvar...', Department of Criminology, Stockholm University.

Diesen, C. 2005. Likhet inför lagen, Stockholm: Natur och kultur.

Diesen, C. 2006. 'Negativ särbehandling i rättskedjans alla led', in: Sarnecki, J. Ed. Är rättvisan rättvis?, SOU 2006: 30, Utredningen om makt, integration och strukturell diskriminering

Dillon, M. 1995. 'Sovereignty and Governmantality', Alternatives, 20 (4): 323-268.

Engstrand, A-K., Andersson, J. \& Vesterberg, V. 2010. Bortom Lissabonstrategin. Department of Social and Welfare Studies, Linköping University.

Eriksen, T. H. 2002. Ethnicity and Nationalism, London: Pluto.

Esping-Andersen, G. 1990. The Three Worlds of Welfare Capitalism, Oxford: Polity Press.

Foucault, M. 1980. Power/Knowledge, New York: Pantheon.

Foucault, M. 1991. 'On Governmentality', in: Burchell, G. et al. Eds. The Foucault Effect, Brighton: Harvester.

Garsten, C. \& Jacobsson, K. Eds. 2004. Learning to be Employable, Houndsmills: Macmillan Palgrave.

Goldberg, D. T. 2009. The Threat of Race, Oxford: Blackwell Publishing.

Gruber, S. 2007. Skolan gör skillnad, Department of Social and Welfare Studies, Linköping University.

Hall, S. 1996. 'New Ethnicities’, in: Morley, D. \& Chen, K. H. Eds. Stuart Hall, New York: Routledge.

Hall, S. 2000. 'Old and New Identities, Old and New Ethnicities', in: Hesse, B. Ed. Theories of Race and Racism, London: Routledge.

Hansen, K. V. 2013. Encounters on the Great Plains. Oxford: Oxford University Press.

Hertzberg, F. 2003. Gräsrotsbyråkrati och normativ svenskhet, Stockholm: Arbetslivsinstitutet.

Hjerm, M. 2002. 'Arbetsmiljö', in: Vogel, J. et al. Eds. Integration till svensk välfärd?, Stockholm: SCB/Arbetslivsinstitutet.

Hörnqvist, M. 2010. Risk, Power and the State, London: Routledge.

Isin, E. F. 2002. Being political, Minneapolis: University of Minnesota Press.

Isin, E.F. \& Wood, P.K. 1999. Citizenship \& Identity, London: Sage.

International Organisation for Migration (2015) Missing Migrants Project: Mediterranean update 18 December 2015, http://www.iom.int/infographics/missing-migrants-project-mediterranean-update-18-december2015 [accessed 2016-01-19].

Jacobsson, K. 2004. 'A European Politics for Employability', in: Garsten, C. \& Jacobsson, K. Eds. Learning to be Employable, Basingstoke: Palgrave Macmillan.

Jonsson, A. \& Wallette, M. 2001. 'Är utländska medborgare segmenterade mot atypiska arbeten?’, Arbetsmarknad \& Arbetsliv, 7 (3): 153-168. 
Junestav, M. 2007. Socialförsäkringssystemet och arbetsmarknaden, Uppsala: IFAU.

Kinberg Batra, A. \& Norlén, A. 2016. 'Svenska värderingar behöver försvaras', Svenska Dagbladet, June 6.

Koopmans, R. \& Statham, P. 2000. 'Migration and Ethnic Relations as a Field of Political Contention', in: Koopmans, R. \& Statham, P. Eds. Challenging Immigration and Ethnic Relations Politics, Oxford: Oxford University Press.

Larsson, J. K. 2015. Integrationen och arbetets marknad. Stockholm: Atlas.

Larsson, B., Letell, M. \& Thörn, H. 2012. 'Transformations of the Swedish Welfare State', in: Larsson, B. et al. Eds. Transformations of the Swedish Welfare State, Basingstoke: Palgrave Macmillan.

Lui, R. 2004. 'The International Government of Refugees', in: Larner, W. \& Walters, W. Eds. Global Governmantality, London: Routledge.

Löfvén, S. 2016. 'Vi backar aldrig från svenska värderingar', Aftonbladet, June 15.

Malkki, L.H. 1997. Purity and Exile, Chicago: University of Chicago Press.

Marshall, T.H \& Bottomore, T. 1992. Citizenship and Social Class, London: Pluto Press.

Miles, R. \& Brown, M. 2003. Racism. New York: Routledge.

Neergaard, A. 2006. 'Rasifierad rekrytering i storstadskommunen', in: Gunnarsson, E. Eds. Kors \& tvärs, Stockholm: Normal.

Ngeh, J. 2011. Conflict, Marginalisation and Transformation, Department of Sociology, Umeå University.

Ong, A. 2006. Neoliberalism as Exception, Durham: Duke University Press.

Procacci, G. 2004. 'Govenmentality and Citizenship', in: Nash, K. \& Scott, A. Eds. The Blackwell Companion to Political Sociology, Malden: Blackwell.

Prop. 2015/16:174. 'Förslag om att tillfälligt begränsa möjligheten att få uppehållstillstånd i Sverige', Government Offices.

Rodrigo Blomqvist, P. 2005. Närvarons politik och det mångetniska Sverige, School of Public Administration, Gothenburg University.

Rose, N. 1996. 'Governing “Advanced” Liberal Democracies', in: Barry, A. et al. Eds. Foucault and Political Reason, London: Routledge.

Rose, N. 1998. Inventing Ourselves, Cambridge: Polity Press.

Rose, N. 1999. Powers of Freedom, Cambridge: Cambridge University Press.

Sassen, S. 2006. Territory, Authority, Rights, Princeton: Princeton University Press

Schierup, C-U., Ålund, A. \& Kings, L. 2014. 'Reading the Stockholm Riots', Race \& Class, 55(3): 1-21.

Schierup, C-U., Hansen, P. \& Castles, S. 2006. Migration, Citizenship and the European Welfare State, Oxford: Oxford University Press.

Schierup, C-U. \& Paulson, S. Eds. 1994. Arbetets etniska delning, Stockholm: Carlssons.

Statistics Sweden 2016a. Statistikdatabasen, http://www.statistikdatabasen.scb.se [accessed 2016-07-25]. 
Statistics Sweden 2016b. Definitioner, http://www.scb.se/sv_/Vara-tjanster/Regionalastatistikprodukter/Fardiga-tabellpaket/Definitioner/\# [accessed 2016-05-03].

Stoler, A.L. 1995. Race and the Education of Desire, Durham: Duke University Press.

Tesfahuney, M. \& Dahlstedt, M. 2008. 'Maze of Camps', in: Holmgren Troy, M. \& Wennö, E. Eds. Space, Haunting, Discourse. Cambridge: Cambridge Scholars Press.

Vesterberg, V. 2016. Ethnicizing Employability. Department of Social and Welfare Studies, Linköping University.

White, M. \& Hunt, A. 2000. 'Citizenship: Care of the Self, Character and Personality', Citizenship Studies, 4 (2): 93-116.

Wright Nielsen, T. 2009. Viljen til at frigore, School of Social Work, Lund University.

Ålund, A. \& Schierup, C-U. 1991. Paradoxes of Multiculturalism, Avebury: Aldersholt. 